IJternational Journal of Social Sciences and Education Research
Online, $\frac{\text { http://dergipark.gov.tr/ijsser }}{\text { Volume: } 5(3), 2019}$

\title{
Inclusion and exclusion in democracies: A theoretical comparison of John M. McCormick and Iris M. Young
}

\author{
Onur Şen ${ }^{1}$
}

Received date: 17 / 03 / 2019

Accepted date: $30 / 06 / 2019$

\begin{abstract}
Elections, as one of the main pillars of modern democracies, are necessary but not sufficient condition for ideal form of representative democracy. John M. McCormick and Iris M. Young problematize the democracy understanding solely based on fair and competitive elections. While they both agree on the problem of modern democracies as executed by wealthy elites, there is a divergence in their proposed solutions. While McCormick sees the problem as inequalities between classes and proposes excluding the wealthy elites from dominating the political representation and decision making, Young proposes an inclusive approach that empowers marginalized groups. This article compares and contrasts these two theoretical approaches to reform democracy in a way that would deliver its promise as a system of comprehensive policy making process.
\end{abstract}

Keywords: Democracy, Inclusion, Exclusion, Deliberative Democracy

\section{Introduction}

The first thing comes to one's mind when he is asked features of democracy, the most common answer would probably be "elections". In modern republics representation and democracy has harmonized at a degree that they are almost used interchangeably. It is election that legitimizes the power of a government in democracies and makes elected governments accountable to the people. It is hard to deny the central position of elections in modern democracies. However, if one is asked the definition of democracy, the answer would probably not be limited to elections. Everyone agrees that elections is an important part of democracy but also agrees that there is more than that. In other words, election is a necessary but not sufficient condition for democracy to exist in its ideal form.

\section{A theoretical comparison of John M. McCormick and Iris M. Young}

Two political theorists, John P. McCormick and Iris M. Young focuses on how to make democracy more inclusive and equal as it promises to be, and how seeing democracy only consisting of election is problematic. Although they address the same problem, their proposed solution is distinctly different from each other. On the one hand, McCormick (2011) sees the core of the problem as inequalities between classes. He proposes that the wealthy people have an enormous advantage over ordinary people in holding public offices. By referring to Machiavelli's Discourses, he argues that a radical constitutional change is necessary in the United States to limit the power of the wealthy and empower common citizens. He is calling for an institutional reform which would empower the common citizens at the expense of excluding the wealthy ones. For me McCormick's theory is an exclusionary one in favor of ordinary people. Only by excluding

${ }^{1}$ Dr., onursenacademic@gmail.com 
Şen, O. (2019). Inclusion and exclusion in democracies: A theoretical comparison of John M. McCormick and Iris M. Young. International Journal of Social Sciences and Education Research, 5(3), 257-262.

the rich from certain political institutions, the poor and middle-income citizens can be empowered. Any other institutional arrangement that does not require exclusion of the wealthy will be dominated by the wealthy citizens.

On the other hand, Young's (2002) solution to create a better democracy is through inclusion of excluded groups. In current form of democracy, certain groups are inherently excluded from decision making process and their voices are not heard by the elites. She does not necessarily see only the poor as the excluded group, although they are one of the many, but she defines excluded groups cross cutting the gender, religious or race related differentiations. She proposes within the existing structure, certain reforms can create necessary venues for excluded citizens to be able to get together and raise their voices. As opposed to McCormick's exclusionist approach, Young proposes an inclusive one through deliberative democracy. In this paper, I will go into the details of both theorists and develop my comparison of the two that mentioned above.

The main question John P. McCormick (2011) is trying to answer in his book called "Machiavellian Democracy" is "what institutions will prevent wealthy citizens from dominating a government that is supposed to serve the entire citizenry?" (p. 1). This question was central in preeighteenth century republics and still valid and not answered by democratic theorist. McCormick takes us to a journey starting from Machiavellian's era to modern democracy in the United States.

By mainly referring to Machiavelli's Discourses on Titus Livy's First Ten Books, he proposes a constitutional change in the United States to address the problem of wealthy citizens dominating modern democracy. Similar to pre-modern democracies where "wealthy individuals and families frequently subverted republican governments, maneuvering them in more narrowly oligarchic or autocratic directions" (p. 1), "modern popular governments are no less vulnerable than their historical antecedents to corruption, subversion, and usurpation by the wealthy" (p. 2).

In doing so, McCormick challenges the "Cambridge School", which sees Machiavelli as a republican who "instructs rulers how they might best manipulate the people" (p.3). For him, the Cambridge School underestimates Machiavelli by ignoring his efforts to empower common citizens to counter balance domination of wealthy citizens. So his reading of Machiavelli's theory is more participatory and in favor of common citizens than republicanism (p.3). Machiavelli proposes necessary institutions to increase elite accountability through assemblies of common citizens with veto and legislative powers, a magistrate selection with a combination of lottery and election and empowering entire citizenry to judge prosecutions in political trials (p. 2).

Contrary to pre-modern democracy's fear of wealthy citizens dominating the power and ordinary citizens, the architects of modern democracy in the United States saw popular majority of ordinary citizens as the biggest threat to the stability of government. Therefore, the US constitution is designed in a way to protect elites from "potentially pernicious" masses (p. 2). Since McCormick's view of a democracy should be the one protecting the ordinary citizens from domination of wealthy minority, the only way to empower masses is through a constitutional change.

The natural question that rises from his proposal of empowering common people through constitutional change is that "can ordinary citizens' capacity for political judgment be trusted?" This skepticism made creators of the US constitution to leave decision making to elites. For Machiavelli, common citizens' capacity for political judgment is underestimated. In "deciding political trials, appointing magistrates, and creating legislation", common people can exercise better judgment than elites (p.65). Therefore, he proposes access of all citizens "to formal and informal 
Şen, O. (2019). Inclusion and exclusion in democracies: A theoretical comparison of John M. McCormick and Iris M. Young. International Journal of Social Sciences and Education Research, 5(3), 257-262.

assemblies within which they deliberatively transform their perhaps initially unconsidered opinion (opinione) into good judgment (giudicio) over laws and candidates for office" (p. 67).

Machiavelli does not go too far to say that people's judgment is always right. McCormick emphasizes on that by saying "Machiavelli insists that the people's judgment happens to be superior to that of other political actors most of the time; he never insists that the people's judgment is always wise or invariably conducive to freedom" (p.83). Based on Machiavelli's trust to common people's political judgment, McCormick suggests that ordinary citizens' judgment is at least as valuable as wealthy elites in the United States. So empowerment of people through constitutional change would not create a noise of masses but will help to ensure that the elites are checked by judgments of the masses.

McCormick defines elites as in modern democracies where "all citizens are formally eligible to hold office...the category "elite" applies technically only to those who do" (p. 91). For him, modern democracies keep elites accountable through "the reward/sanction scheme of election and prospective reelection; the institutional counter position of functionally separated powers; and, in extreme cases, the threat of removal through impeachment procedures conducted by other public officials" (p. 91). He finds this structure "odd, unjust, and dangerous" even in premodern standards (p. 91). Since the rich has better skills and resources to run an election campaign, the public offices will be dominated by them and not distributed in a way that would be representative of citizens of all socioeconomic backgrounds (p. 92).

To deal with the problem of elite domination of public offices, McCormick gives examples of lotteries or sortitions used in ancient democracies. His example of the tribunes of the plebs in Rome is important for his proposition of a similar institutional arrangement for modern democracy in the US. The way he describes how the tribune works in Rome is with this quotation from Machiavelli: "It (a tribune) was good that anyone who cared for the public good could propose laws, and that everyone could speak their mind on it so that the people could subsequently choose what was best" (p. 77). The tribunate played a vital role in Rome's success at attaining "liberty and glory" as it had great power to protect plebeians over oppression of the grandi (p.93). Other than protecting the plebeians, the tribunate served as mediators between the nobles and the people as well as among the nobles as they would consult to tribunate when they have a dispute among themselves (p. 94).

McCormick adapts political theory of Machiavelli and his emphasis on empowering ordinary citizens over elites, and applies it to modern democracy in the United States. He problematizes electoral democracy by stating that "the republican-inherited "minimalist" criterion of popular government generally agreed upon by both sets of democratic theorists -namely, periodic selection of public officials for specific terms of office by populace enfranchised with universal adult suffrage - seems less and less sufficient to guarantee citizens' liberty in contemporary democracies" (p. 171). The problem with electoral government is its inability to keep elites accountable and limit wealthy citizens' influence on government.

In modern democracies, whether it is proportional representation or "winner-take-all" electoral systems, the party and union has a tremendous advantage in terms of information and power compared to ordinary members of political organization (p. 173). To address these problems of electoral model, he proposes a substantial amendment to the US constitution that would create an elite-accountability institution, a revived tribunate, which "combines element of randomization, wealth-exclusion, and direct plebeian judgment" (p. 171). 
Şen, O. (2019). Inclusion and exclusion in democracies: A theoretical comparison of John M. McCormick and Iris M. Young. International Journal of Social Sciences and Education Research, 5(3), 257-262.

The tribunate that McCormick envisions is "a People's Tribunate of fifty-one lottery-selected, nonwealthy citizens" who would serve for one-year nonrenewable terms (p. 183). It would have the power to veto one piece of congressional legislation, one executive order, one Supreme Court decision and can initiate impeachment proceedings against one federal official every year (p. 183185).

Jeffrey Winters (2012), in his critical review of McCormick's book, rightly acknowledges that McCormick's "target is not wealth stratification" (p. 140). He does not mention about any Marxist ideas like redistribution of wealth or proletariat revolution. He is not against the existence of a wealthy class in the society. Rather his problem with inequality is that wealth distorts representative government. As a solution he proposes what Winters calls as "power reorientation" that can be "used by the many against the few to pursue economic equality" (p. 141). For Winters, McCormick's proposal of a People's Tribunate attacks modern democracy fundamentally in three ways. Firstly, a deliberative and selective exclusion of the wealthy should be adapted to reach a better democracy. Secondly, in addition to branch and functional division of institutions, a class-based separation of institutions is also necessary for a full democracy. Lastly, instead of "hegemony of elections", greater representation of the people can be achieved through lotteries (p. 141).

The main critique of Winters, which I also echo here, is how to get "American oligarchs to accept a People's Tribunate" ( $p$.142). Forcing the elite to give up their dominant position necessitates a huge mobilization of the ordinary citizens. Even if this mobilization happens, the wealthy will "use all means at their disposal to obstruct the creation of a powerful institution" (p. 142). If the political structure is dominated by the wealthy minority, why should we expect them to give up their power to ordinary citizens, who will cause them a lot of headache.

Although McCormick gives specific roles that People's Tribunate will play, he does not really gives enough explanation on how to create a tribunate in modern United States. "Do the conditions that led to the creation of tribunates in Rome exist in modern democracies?" is an unanswered question. McCormick (2012) in his response to Winters's critique a mechanism of collective threat that forced Roman elites to give concessions to plebeians exists in the nineteenth and twentieth centuries as well. Just like ancient plebeians used the threat of withholding their warmaking capacities, worker-citizens in modern times can threaten to withhold their labor power from industrial economies (p. 143).

Another valid critique is that McCormick's basing his arguments to only one example of Rome, where the power of the tribunate, according to Winters, is exaggerated. He asks the question of "whether Rome was a democracy with oligarchic elements or an oligarchy with democratic elements" (p. 142). He warns us that in Roman era the plebs were a minority of free white male with senators and knights above them and millions of slaves and farmers below them. So not only the power and influence but also the representativeness of the tribunate in Rome is questionable.

Iris Marion Young in her book called "Inclusion and Democracy" (2002) problematizes democratic processes and proposes more inclusion as a solution to shortcomings of modern democracies. While democracy is expected to be inclusive in decision making, structure and institutions of current democracies in fact paralyze this end. Structural inequalities and exclusion of certain groups from policy making are the main problems of democracy according to her. Therefore, she proposes inclusion to develop a democracy that actually can accomplish what is expected from a democratic process. 
Şen, O. (2019). Inclusion and exclusion in democracies: A theoretical comparison of John M. McCormick and Iris M. Young. International Journal of Social Sciences and Education Research, 5(3), 257-262.

She approaches democracy from two main models, aggregative and deliberative, and favors the later. For her, only deliberative democracy can fulfill the promises of democracy as an inclusive policy making process and she develops and advocates this model of democracy throughout the book. Her key concept is inclusion and for her only an inclusive form of democracy can solve problems of democratic processes.

She adopts a minimalist definition of democracy as "...democratic politics entails a rule of law, promotion of civil and political liberties, free and fair election of lawmakers" (p. 5). Although she can be criticized for choosing a minimalist definition of democracy while trying to develop a theory that democracy means much more than those principles in the definition, I find this definition useful for her argument for two reasons. Firstly, starting her theory with a commonly agreed definition of democracy makes her argument more inclusive which is her goal. This broad definition is acceptable for people from all sides of the spectrum on democratic theory. Secondly, she quickly moves her argument one step ahead by stating that expectations from a democratic process is much more than the minimalist definition. It is smart on her side to develop a more inclusive theory democracy by starting with defining what it means in minimalist terms.

She defines two models of democracy and favors one over the other. The first model of democracy she defines is the aggregative model which is "a process of aggregating the preferences of citizens in choosing public officials and policies" (p. 19). In this model, democracy is competition between parties in order to address preferences of the largest number of people. The second model of democracy is the deliberative model where "participants in the democratic process offer proposals for how best to solve problems or meet legitimate needs, and so on, and they present arguments through which they aim to persuade others to accept their proposals" (p. 22). This model has four normative ideals which are inclusion, equality, reasonableness and publicity. In other words, it is a process of inclusion where participants equally make reasonable proposals in public.

For the purpose of this paper, it is beneficial to focus on Young's discussion on participation and representation. She rejects the idea of seeing participation as an opposition to representation. She acknowledges that "the web of modern social life often ties the action of some people and institutions in one place to consequences in many other places and institutions" (p. 124). Therefore it will not be realistic to expect a person to be present at all the decision-making bodies. On the other hand, representation limits "authentic democracy" in the sense that represented is not identically same as the representative. For her, if we say that representation is necessary but representative should be identical with the constituency, then we are asking for impossible (p. 126). The way out of this paradox for her is not to see representation as a part of identity but rather to see it "as a process involving a mediated relation of constituents to one another and to a representative" (p. 127). So for her a good representation is one that "establishes and renews connection between constituents and representative" (p. 130).

Given the definition of good representation, Young proposes how marginalized groups should be represented. She defines marginalization of groups as "structural social and economic inequality often produces political inequality and relative exclusion from influential political discussion" (p. 141). As a remedy to this problem she proposes that "more inclusion of and influence for currently under-represented social groups can help a society confront and find some remedies for structural social inequality" (p.141). She also emphasizes the role of civil society as a deliberative platform where marginalized groups can raise their voice. However, deliberative effectiveness of 
Şen, O. (2019). Inclusion and exclusion in democracies: A theoretical comparison of John M. McCormick and Iris M. Young. International Journal of Social Sciences and Education Research, 5(3), 257-262.

civil society is questioned by Simone Chambers (2009), who claims that broad informal public sphere cannot be deliberative (p .324). He proposes that for better deliberation "the mass public should be abandoned in favor of mini-publics" (p. 324). He makes a distinction between democratic deliberation and deliberative democracy and argues that only the latter can offer a real deliberation as it focuses on "discrete deliberative initiatives within democracies" as opposed to tackling "the large questions of how the public, or civil society in general, relates to the state" (p. 324).

A similar critique that is directed to McCormick can be directed to Young that how and why the prioritized groups would give up their power to the marginalized groups and even if they do why they should listen to marginalized groups' proposals. In McCormick's case answering this question was more difficult in the sense that he was calling for a substantial constitutional change in a system that is dominated by the wealthy. Young's proposal of inclusion is relatively modest and more feasible within the existing political structure. Archon Fung (2005) addresses this question in a more partisan way that he proposes a deliberative activism in order for dominant groups to yield for the demands of exclusion by the marginalized. Instead of persuasion, he proposes that the excluded groups should take a more activist stance against the dominant groups.

\section{Conclusion}

In conclusion, when McCormick and Young is compared and contrasted both similarities and difference in their arguments can be found. As I mentioned at the beginning of this paper, they both address the insufficiency of elections as delivering the promises of democracy to citizens. Although they address the same question, their solutions are pretty different from each other. McCormick's call for exclusion of the wealthy in favor of the ordinary citizens and Young's call for inclusion of under-represented groups regardless of their socio-economic status appears to be the most notable distinction between the two.

\section{Bibliography}

Chambers, S. (2009). "Rhetoric and the Public Sphere: Has Deliberative Democracy Abandoned Mass Democracy?" Political Theory 37 (3), 323-350.

Fung, A. (2005). "Deliberation Before the Revolution: Toward an Ethics of Deliberative Democracy in an Unjust World." Political Theory 33 (3), 397-419.

Manin, B. (1997). The Principles of Representative Government. Cambridge, Cambridge University Press.

McCormick, J. P. (2011). Machiavellian Democracy. Cambridge, Cambridge University Press

McCormick, J. P. (2012). "Response to Jeffry Winters's Review of Machiavellian Democracy”. Perspectives on Politics 10 (1), 143.

Olson, J. (2004). The Abolition of White Democracy. Minneapolis, University of Minnesota Press.

Pateman, C. (1976). Participation and Democracy Theory. Cambridge: Cambridge University Press.

Winters, J. (2012). Review: Machiavellian Democracy. Perspectives on Politics 10 (1), 140-143.

Young, I. M. (2002). Inclusion and Democracy. Oxford, Oxford University Press. 